\title{
UMA HISTÓRIA DA IDÉIA DE UTOPIA: O REAL E O IMAGINÁRIO NO PENSAMENTO POLÍTICO DE THOMAS MORUS
}

\author{
A history of the idea of utopia: reality and imagination in \\ the political thought of Thomas More
}

\author{
Marcos Antônio Lopes*
}

\begin{abstract}
RESUMO
Morus não é o criador do pensamento político utópico, mas é o teórico que fez circular o ideal utópico, em sua corrente mais influente. Foi ele quem criou a palavra Utopia. Morus foi o primeiro a criticar a ordem social orientada pela exploração do trabalho e pela força do dinheiro. Ele é crítico da agricultura intensiva que leva à desestruturação das comunidades agrárias. Como Maquiavel, ele transita pela esfera do poder, uma esfera de ligações perigosas. De um modo diferente, ele tentou também separar a ética da política. Este artigo analisa estes aspectos de seu pensamento político.
\end{abstract}

Palavras-chave: pensamento político, Thomas Morus, utopia.

\begin{abstract}
Morus is not the creator of the utopian political thought, but it is the theoretical that makes to circulate the utopian ideal, in its more important version. It went him who created to word Utopia. Morus was the first to criticize the social order guided by the exploration of the work and for force of the money. He is critical of the intensive agriculture that upside down the agrarian communities. As Maquiavel, he walk for the sphere of the power, a sphere of dangerous connections. In a different way, he also tried to separate the ethical of the politics. This article analysis these aspects of its political thought.
\end{abstract}

Key-words: political thought, Thomas Morus, utopia.

A Utopia continua sendo uma obra excepcionalmente desconcertante, com uma profundidade de ironia que às vezes é difícil acompanhar (...) O tom de Morus sem

* Departamento de Ciências Sociais da Universidade Estadual de Londrina 
dúvida sempre continuará a afetar cada leitor de uma forma distinta.

Quentin Skinner

Moro intentaba regresar a una filosofía cristiana del hombre, a una "antropología" que fuese, a diferencia de la escolástica, incorregiblemente cristiana. (...) Moro considera que el cristianismo era el proceso de divinización del hombre.

Kenneth Rexroth

In any case, there can be little doubt, after four hundred years (...) Thomas More is, like Shakespeare, like Socrates, like Michelangelo, a man for all seasons.

Peter Burke

A man for all seasons - título de uma biografia romanceada de Thomas Morus (1478-1535), de autoria do escritor Robert Bolt, e que deu origem a um filme de idêntico título, estrelado por Charlston Heston - é bem a expressão do intelectual que, por seus elevados princípios éticos, encontra espaço e lugar em qualquer época. Com efeito, os comentadores da obra de Morus apontam para o fato de que sua repercussão ao longo dos séculos tem sido mais notável por seu exemplo pessoal do que pela influência de seus textos, exceção feita à Utopia. Jean Touchard lembra, a este propósito, que "a influência de Morus ultrapassa a de um simples êxito literário” (TOUCHARD, 1970, p. 34). Mas a imagem do homem santo - ele foi canonizado pela Igreja em 1935 - tem sido também contrastada com a do implacável perseguidor de hereges. Há muitos aspectos de sua personalidade que revelam um Morus histórico que foge bastante ao padrão do intelectual tolerante. Seus combates intelectuais contra Lutero se assemelham a uma renhida disputa medieval, na qual estão em jogo complicadas questões de dogma.

Da mesma forma, a maior parte de seus textos exala ares de quinquinharias da Idade Média, destroços intelectuais com valor meramente arqueológico. Ele é, portanto, um autêntico fóssil filosófico. Nova exceção feita à Utopia. Para Anthony Kenny, "o estilo e forma da Utopia é obra do Renascimento: não é possível imaginar um tratado político medieval sucetível de tão variadas e contraditórias interpretações” (KENNY, 1992, p. 135). Mas a imagem de Morus que predomina em nossos dias é mesmo a do humanista virtuoso em meio à sua resistência heróica contra os desmandos do rei. Sobre esta resistência ele deixou uma passagem literária célebre. Instado por sua filha Margareth Roper a assinar a Lei de Sucessão, em meio às piores perspectivas de obter a pena capital, ele encontrou energia moral para retrucar: "Um homem pode perder a cabeça sem sofrer dano" (KENNY, 1992, p. 107). Este artigo é, ao mesmo tempo, uma análise sobre o "lugar" do humanista cristão no plano mais 
amplo de uma história intelectual, e também uma discussão sobre a idéia de utopia. ${ }^{1}$

AEuropa Renascentista foi uma civilização que desejou ousar, e ousou efetivamente. De fato, o século XVI representa um grande marco na história do Ocidente. Foi nesse período que se deu a grande arrancada, a decisiva "decolagem" do mundo cristão, promovido, a partir daí, à categoria de civilização de vanguarda. Na época do Renascimento, as sociedades européias desenvolveram um tal número de novos conhecimentos e técnicas, principalmente as relacionadas ao domínio da arte da guerra, que se colocaram na dianteira de civilizações de culturas até então mais antigas, mais exuberantes e sofisticadas como, por exemplo, a árabe e a chinesa.

Entretanto, a Europa do Renascimento foi uma civilização de contrastes: abandonou as visões quiméricas da Idade Média, como o antigo ideal das cruzadas e o sonho de uma cristandade sem fronteiras nacionais, expresso pelo já bastante anacrônico Sacro Império Romano Germânico, para construir novos mitos e alegorias nas mais desencontradas direções. A civilização do Renascimento foi um universo saturado de sonhos, onde pulularam arquitetos de mundos imaginários, estimuladores de ambições delirantes que nunca existiram na prática. $\mathrm{O}$ fascínio exercido pela tradição greco-romana, encarada não como modelo a imitar, mas como fonte de inspiração para novas criações nos campos social e da cultura, amorteceu nas elites letradas da Europa a concepção obsessiva de temas religiosos. No século XVI assiste-se a uma forte valorização da literatura profana, em detrimento da crônica sagrada, com suas vidas de santos a imitar. Maquiavel, Rabelais, Marguerite de Valois, entre tantos outros escritores, expressam a dimensão demasiada humana da vida.

Em um mundo de cultura exuberante, mas também pleno de insegurança provocada pelos intermináveis conflitos, fossem eles as guerras tradicionais entre os poderosos do tempo, fossem as guerras de religião entre católicos e protestantes, era natural que as sociedades assoladas também pela fome e por epidemias buscassem formas de evasão do mundo. Daí o florescimento de um número considerável de utopias, paradoxalmente consideradas em sua própria época como "brincadeiras sérias", nas quais se idealizavam sociedades afortunadas, regidas por leis muito diferentes dos rígidos preceitos que ordenam a vida cotidiana. E as utopias do século XVI desejaram fazer passar por concreto o que era exagerado e o que contrariava frontalmente as duras regras da vida

1 Os vários sentidos do termo são discutidos com argúcia por Moses FINLEY, (1989, p. 193 et seq. ) e por Marcel PRÉLOT, (1974, p. 70, v. 2). 
real, refletindo um forte pessimismo em relação ao presente e uma grande esperança no futuro. Como afirma o historiador francês Jean-Christian PETIFILS (1977, p. 16),

após um longo período de eclipse na Idade Média, o utopismo volta a surgir no século XVI, quando as grandes descobertas, as transformações sociais e o progresso técnico passaram a questionar os fundamentos e os valores do mundo medieval. ${ }^{2}$

A literatura, bem como a pintura do século XVI, estão repletas desses motivos fantásticos, desses jardins de delícias que refletem a necessidade de fuga, o desejo de evasão de um mundo que, na prática, se revela extremamente cruel e infeliz. E a imprensa nascente foi a grande vendedora de sonhos: produziu em toda a Europa do século XVI centenas e centenas de edições de histórias de aventuras. Muita razão tem o historiador católico Jean DELUMEAU (1984) ao afirmar que o Renascimento teve, por vezes, mais ambição que razão. Assim, a literatura criou uma infinidade de paraísos terrestres em que a vida era cor de rosa e onde só havia espaço para a diversão, a música e o amor. Um exemplo célebre desses mitos literários do século XVI é a fonte da juventude, para onde são conduzidos os velhos, os doentes e os estropiados, que após um breve mergulho saem jovens e alegres para desfrutarem de festas, cantorias e do amor, para sempre.

Mas existiram, ainda, os sonhos populares do Renascimento, que apesar de menos requintados, também foram retratados pelas artes. A miragem mais interessante no universo das aspirações de artesãos e camponeses pobres dessa época talvez seja a representação dos países da fartura, a "terra de cocanha", mundos onde não é necessário trabalhar para ganhar a vida. Numa pintura flamenga do século XVI está retratado, entre diversas cenas bucólicas de abastança sem limites, um camponês sendo encarcerado com a seguinte explicação: "Vai preso porque trabalhou". (DELUMEAU, 1984).

Um utopista do Renascimento, o escritor francês Rabelais, edificou idealmente a cidade de Telema, paraíso no qual a única divisa era "faze o que quiseres", onde só entravam mulheres belas e educadas e homens virtuosos e

2 "As utopias estavam então em voga - um escoadouro para as idéias dos homens sobre o governo e a conduta, concebidas no verdadeiro espírito renascentista, com o fato e a fantasia ricamente entretecidos (...). A República de Platão, juntamente com as narrativas correntes de novos mundos, movera a imaginação dos homens". (SICHEL, 1977, p. 107). Sintomático que o personagem central de Morus seja um navegador português, Raphael Hythlodey. 
perfeitamente corteses. Nesse mundo imaginário pagavam-se cinco dinheiros por dia para quem quisesse apenas dormir e sete dinheiros e meio para aquele que se dispusesse a um maior esforço: roncar. Nessas estâncias maravilhosas, pedaços de tortas caem dos telhados, existem montes de puro parmesão gratinado e regatos de um delicioso vinho branco onde não corre sequer uma gota d'água. E com um detalhe: este paraíso é eterno. Na cidade de Nápoles, representava-se uma vez por ano a festa da cucagna: improvisava-se em praça pública uma imagem do Vesúvio, de cuja erupção saía muita salsicha, carne cozida, macarrão e queijo ralado. A terra de cocanha foi uma miragem que representou os anseios dos homens pobres do Renascimento e uma recusa obstinada, por meio da imaginação, da precariedade da vida. A terra de cocanha é uma utopia do imaginário popular do início da Era Moderna, que tenta fornecer aos homens aquilo sobre o qual se sentem muito frustrados em não possuir. É um país de compensação às realidades mais duras, que opõe à fome e à pobreza, o luxo e a abundância de alimentos. É, sobretudo, uma mensagem contra o trabalho e a morte. Por meio da literatura, e principalmente pelo emprego do estilo romanesco, a parcela culta das sociedades renascentistas passou a sonhar com paraísos terrestres, com deusas e fadas habitando em palácios encantados, universos imaginários abertos a qualquer pessoa.

Contudo, houve aqueles construtores de mundos imaginários que não enveredaram por estas terras de ócio e fruição ilimitada dos "sonhos de consumo" das pessoas pobres daquele tempo, mas que preferiram conceber sociedades perfeitas, ressaltando a importância transformadora do trabalho. Eles foram grandes intelectuais e tentaram erigir, utilizando-se de muita imaginação, mas também de uma boa margem de pragmatismo e razão, a república ideal para o gênero humano. Suas obras foram sistemas filosóficos complexos, e exerceriam, por longo tempo, considerável influência. Em relação à terra da fartura, poderíamos chamar estas outras miragens sociais de "utopias científicas", devido ao seu conteúdo uniformizador e racional. Como afirma Hilário FRANCO JÚNIOR (1998, p. 201), autor de um excelente livro sobre a terra de cocanha, "na verdade esses países utópicos das elites representam, intencionalmente ou não, a negação da Cocanha".

O livro do humanista cristão Thomas Morus (1578-1535) talvez represente o mais célebre desses mundos fantásticos em que se escaparia de todas as injustiças. Como observa o historiador alemão Walter THEIMER (1970, p. 304), "a utopia clássica da idade moderna é a Utopia de Morus, que deu nome a toda a corrente". Em sua obra Utopia, Morus descreve a vida numa ilha 
em formato de lua crescente, na qual tudo é dividido de maneira eqüânime entre as pessoas, onde não existe injustiça e violência e se vive confortavelmente.

Thomas Morus nasceu e passou a maior parte de sua vida em Londres. Pensador de elevada expressão, foi ovacionado em seu próprio tempo, alcançando notoriedade em toda a Europa. Quentin SKINNER (1996, p. 234) qualifica-o como "o maior e mais original" humanista radical inglês do século XVI. Ao rigor das idéias, Morus aliava sempre "uma palavra de uma só vez maravilhosamente inteligente e agradavelmente cordial" (SARGENT, [s.d.], p. 225), o que fez com que sua celebridade crescesse ainda mais. ${ }^{3}$ Amigo íntimo de Erasmo, Morus viveu numa Europa marcada pelas desigualdades e injustiças sociais. A Inglaterra de Morus era uma terra na qual, segundo ele mesmo, "carneiros devoravam homens", uma alusão metafórica à lei dos cercamentos (enclosures acts), que implicou no desterro de inúmeras comunidades camponesas e na dissolução gradativa das tradições comunais, que remontavam à Idade Média. ${ }^{4}$ Acerca dessa metáfora agrária de Thomas Morus, a idéia de que os carneiros desestruturam o mundo camponês na Inglaterra dos inícios da Época Moderna, Ruggiero ROMANO e Alberto TENENTI (1972, p. 11) observam: "um exagero, sem dúvida, mas também um valioso testemunho de um processo de transformação".

A crítica mordaz das questões sociais de sua época nos dá uma medida mais exata das implicações políticas de sua Utopia: ele queria eliminar a distância social existente entre as classes abastadas e os numerosos pobres de seu tempo. Morus teve a pretensão típica de um humanista cristão: reduzir a pobreza fazendo a riqueza recuar a patamares compatíveis com os de uma sociedade fraterna. E isto seria possível, segundo está expresso em sua obra, se todos recebessem tratamento indiferenciado em um novo ordenamento hierárquico.

$\mathrm{Na}$ verdade, na ilha de Utopia, o problema da exclusão social, tema candente de seu tempo, e ainda do nosso, seria resolvido de uma vez por todas. E de que maneira? Pela aplicação de todos ao trabalho, sem a menor possibilidade da existência de privilégios. Como não haveria mais espaço para o orgulho

3 Uma referência da proverbial bonomia de Morus foi deixada num registro literário de época. No texto intitulado "Erasmo a Thomas More, saúde", que abre o livro O elogio da loucura, Erasmo se dirigiu a Morus nos seguintes termos: "Mas, assim como, pela excelência do gênio e de talentos, estás acima da maioria dos homens, assim também, pela rara suavidade do costume e pela singular afabilidade, sabes e gostas, sempre e em toda parte, de habituar-se a todos e a todos parecer amável e grato" (ERASMO, 1979, p. 4). Sobre traços da personalidade de Morus e, inclusive, sobre suas caracetrísticas físicas cf. SICHEL, 1977, p. 96.

4 "Os carneiros consomem, destroem e devoram campos inteiros, casas e cidades" (MORUS, apud. SABINE, 1964, p. 421). Como explicam Gaetano Mosca e Gaston Bouthoul, "em decorrência da crescente exportação de lãs inglesas para Flandres, haviam-se transformado em pastagens um grande número de terras outrora cultivadas com cereais" (MOSCA; BOUTHOUL, 1987, p. 134). 
insolente da nobreza indolente e perdulária, o que afastaria de uma vez por todas a possibilidade de acúmulo de riqueza, todos os bens produzidos socialmente seriam repartidos em igual proporção entre todos os cidadãos. Para o fim da abastança de alguns e da carestia de muitos, bastaria que todos os homens se aplicassem a uma jornada de trabalho de seis horas diárias. Isto seria suficiente para sustentar as condições materiais de vida num patamar adequado para os utopianos.

$O$ resultado de uma tal ordem: os homens poderiam cultivar as virtudes do espírito por meio da leitura e da reflexão. ${ }^{5} \mathrm{E}$ qual seria a forma de governo neste mundo de trabalho e de reflexão? Um regime monárquico de soberania temperada. Como lembra PETIFILS, (1977, p. 19) "um monarca reina sobre a ilha. Eleito vitaliciamente por um senado que representa as principais famílias, ele pode ser afastado, mas apenas por motivos de tirania". De fato, a figura execranda do tirano - problemática central do pensamento político na Idade Média -, é sempre um tema recorrente da filosofia política ao longo de todo o século XVI.

O contexto de produção da Utopia é o das transformações da política e da economia provocadas pela expansão européia. A descoberta da América e da nova rota marítima para o Oriente alteraram a percepção dos homens do século XVI. Uma nova cosmovisão surgiu com o Renascimento e fez a cultura política européia girar em muitas direções. A expansão progressiva do comércio internacional desequilibrou as economias agrárias das antigas monarquias européias, a da Inglaterra à frente. Isto porque, antes dos demais reinos da Europa, a Inglaterra se engajou em atividades produtivas que formariam, dois séculos e meio mais tarde, o embrião da Revolução Industrial. Esta realidade econômica em rápida transformação pôs em movimento extratos sociais novos, gente desgarrada de suas antigas comunidades rurais. Homens treinados em luta e que fizeram carreira na "arte da guerra", ${ }^{6}$ ao serem desmoblizados, não mais encontravam ocupação com que garantir o seu sustento.

O século XVI na Inglaterra foi um tempo em que hordas de vagabundos e de salteadores espalhavam a insegurança pelas cidades e estradas. ${ }^{7}$ Como afirma o historiador norte-americano George SABINE (1964, p. 421):

5 "O trabalho é obrigatório para todos, mas com o limite de seis horas por dia, a fim de que todos possam ter lazer e cultivar o espírito ao menos dez horas por dia. A mais nobre das tarefas é a agricultura, e ninguém está isento dela" (GALAND 2001, p. 714).

6 Título de um pequeno livro de Maquiavel. Edição brasileira: A arte da guerra e outros ensaios (cf. MAQUIAVEL, p. 1982). Num tempo em que a guerra é a regra, e a paz uma circunstância meteórica, os especialistas em luta (condotieri) formam uma prestigiosa e bem remunerada elite social.

7 “...numerosas pessoas estavam habituadas a ganhar a vida pelo exercício profissional das armas. Quando as guerras chegaram a seu termo, grande número de antigos combatentes transformaram-se em salteadores que tornavam as estradas pouco seguras assim como as propriedades particulares" (MOSCA; BOUTHOUL, 1987, p. 134). 
a criminalidade tornara-se alarmantemente comum e era combatida pela correspondente selvageria do direito criminal; mas, ainda assim, de nada valia a severidade, pois o crime era o único meio de vida ao alcance de grande número de indivíduos.

E acerca da dureza inócua das penas aplicadas em seu tempo Morus indagava: "Que outra coisa fazemos senão formar ladrões e puni-los?" (SABINE, 1964, p. 421) ${ }^{8}$ É bom lembrar que a severidade dos tribunais, normalmente excessiva e da qual o melhor exemplo foi a intrepidez e o fino humor do próprio Morus a caminho do cadafalso, choca apenas a sensibilidade de nossa época. Exemplar acerca deste aspecto da índole de Morus é o episódio de sua execução. Ao tentar subir num patíbulo frágil e prestes a desabar, ele se dirige ao chefe de seus executores nos seguintes termos: "Rogo a ti, senhor tenente, que me ajude a chegar a salvo lá encima e deixa que de minha descida eu mesmo me encarregarei” (KENNY, 1992, p. 118.). Como elemento dos costumes ingleses do século XVI, a barbárie dos suplícios nas fogueiras da Inquisição e as penas sangrentas como a tortura e a mutilação eram vistas como algo socialmente aceitável, num tempo em que a justiça é dura e inflexível e transforma os magistrados - ao menos em tese, juízes neutros - em algo não muito melhor do que carrascos. Ainda não chegou o tempo de se pensar naquilo que John Locke irá professar como uma prefiguração do Iluminismo: a aplicação de penas brandas e avaliadas conforme as circunstâncias com o precípuo objetivo de recuperar o transgressor da lei para o convívio na sociedade.

No século XVIII o jurista italiano Cesare Beccaria radicalizou esta visão numa obra que se tornou célebre e que foi muito apreciada pelos filósofos do Iluminismo, Dos delitos e das penas. Em seu livro, o filósofo milanês defendia a proporcionalidade entre crime e castigo e a preocupação com a reinserção social do delinquiente. A lógica de Beccaria era "punir para recuperar", excluindo de vez a tortura, a mutilação e outras práticas menos condizentes com os ideais humanitários da Filosofia das Luzes. A regra básica a extrair das lições de Beccaria, e nas quais Voltaire se inspirou, era a de que não se deveria mais punir o ladrão do mesmo modo que o assassino, sob pena de transformar os que roubam em homicidas.

8 O trecho completo do texto de Morus é lembrado por Bernard Galand: "Se tolerais que a gente do povo seja mal ensinada e corrompida desde a infância, e se a punis quando ela atinge a idade adulta por crimes que, digamos, ela sugou com o leite, porventura não estareis criando ladrões para castigá-los em seguida?" (Morus apud GALAND, 2001, p. 713). 
A obra de Morus apresenta alguns traços inovadores em relação à teoria política tradicional da Idade Média - da qual está bem próxima em termos cronológicos -, não deixa de se inscrever na tradição literária medieval miroir des princes como, aliás, sugere Quentin Skinner. ${ }^{9}$ E certamente muito mais pela intenção do que pelo método. ${ }^{10}$ É considerável o esforço de Morus em dirigirse aos monarcas de seu tempo, sobretudo a Henrique VIII, com quem teve uma relação profissional muito próxima. Foi exatamente pela insistência em deixar suas lições morais aos reis e aos poderosos do mundo que ele teve sua vida ceifada com a violência típica aplicada em seu tempo. ${ }^{11}$ Neste sentido, é persuasiva a reflexão do historiador inglês Daniel Sargent, que coloca em evidência a coragem do homem que enfrentou a prepotência típica de um rei obstinado: "O machado cai sobre esta palavra - traição - separando de seu corpo aquela cabeça que, em um mundo cheio de revoltas e desordem, cometeu o equívoco de querer ser fiel à consciência". (SARGENT [s.d.], p. 374). ${ }^{12}$ Como afirma Bernard GALAND (2001, p. 714), "é espantoso que o autor de uma obra tão revolucionária tenha sido primeiro-ministro de um soberano europeu do século XVI". ${ }^{13}$ E Morus foi condenado à morte por não assinar a Lei de Sucessão. E não por ser contra aos princípios políticos que a lei estabelecia, mas por não concordar com a ilegalidade do matrimônio do rei, que as Universidades e o Parlamento haviam afirmado. (cf. KENNY, 1992, p. 97). O drama de consciência de Morus não implica no fato de ele ter sido um defensor empedernido do papa. Ele não era papista, mas católico fervoroso. Assim sendo, não lhe importava que os seus princípios fossem verdadeiros ou falsos. A sua profissão de fé estava no fato de que possuía crença inabalável nestes princípios.

Pois bem, o que vem a ser Utopia? O termo é rico, complexo e escorregadio e, por isto mesmo, comporta sentidos variados e até mesmo

9 "Morus assim aceita, ainda que com alguma ironia, que a posição mais correta que um teórico da política deve ocupar é a de conselheiro do príncipe" (SKINNER, 1996, p. 274).

10 Confira a análise de Kenneth REXROTH (1993, p. 148), da qual discordamos em parte.

11 "Resté catholique, tout em préconisant une réforme de l'Église, il désapprouva le divorce d'Henri VIII, fut empriosenné et executé” (ROBERT, 1997, p. 1426).

12 Renato Janine Ribeiro considera que o problema de Morus relaciona-se com uma grave crise de ordem moral, mas que tocava em seríssimas questões de ordem política: a sucessão ao trono da Inglaterra. Para Ribeiro, "O grande problema para um monarca era assegurar sua sucessão: se não entendemos isso, sempre pensaremos, por exemplo, que o maior acontecimento da história inglesa antes da Guerra Civil - a ruptura com Roma, a Reforma anglicana - terá resultado apenas da luxúria ou da loucura de Henrique VIII, obcecado por problemas matrimoniais" (RIBEIRO, 2002, p. 379).

13 Como lembra Keneth Minogue, "Acertadamente, vemos a vida na corte, no início da era moderna, como um mundo sinistro, melodramático - lembramo-nos de Thomas Morus ("servo fiel do rei, mas primeiro de Deus)" (MINOGUE, 1988, p. 49 et seq.). Curiosamente, a frase entre aspas é de Morus, e havia sido ditada a ele em tom de imperativo categórico de ofício pelo próprio Henrique VIII, por ocasião de seu ingresso na Chancelaria, em substituição a Wolsey (cf. KENNY, 1992, p. 110). 
antagônicos. ${ }^{14}$ Para Nicola ABBAGNANO (1985, p. 949), Thomas Morus "intitulava assim uma espécie de romance fantástico... no qual relatava as condições de vida numa ilha desconhecida denominada propriamente Utopia". No decurso dos séculos, o termo tornou-se alvo de diversas interpretações, não ficando somente em construções similares à de Morus, mas traduzindo, em geral, tanto no passado quanto no futuro, todo ideal político, social ou religioso de difícil ou impossível realização. Os elementos vitais das utopias aparecem sempre preservados: o descolamento da realidade concreta do mundo e o ideal de igualdade e fraternidade entre os homens. Neste sentido, Moses FINLEY (1989, p. 193) afirma que "Todo pensamento utópico tem um elemento de fantasia, de sonho, ou pelo menos de anseio, de uma vida melhor e de um mundo melhor".

A utopia de Morus, como qualquer outra, representa uma contradição com as condições objetivas da existência, vinculando-se também o mundo moral. Como toda utopia, transcende o seu momento histórico, e o seu caráter é de transformação, no sentido de propor uma diferente ordenação das estruturas sociais e das condições materiais de existência. Justiça, liberdade, trabalho, concebidos por um novo viés, são conceitos centrais em sua filosofia política. Como se pode observar, uma utopia política tem como propósito prescritivo a instauração de um Estado ideal, em franco contraste com as condições objetivas da realidade. No dizer de FINLEY (1989, p. 195), "Idéias e fantasias utópicas, como todas as idéias e fantasias, nascem de uma sociedade da qual elas são uma resposta". Mas Morus não foi um visionário ou um lunático. O ideal de constituição de uma sociedade mais justa surgiu da inspiração de um humanista de relevo, um dos maiores intelectuais de seu tempo e, depois de Maquiavel, o autor político mais conhecido do século XVI, apesar da existência de Jean Bodin, outro gigante do pensamento político. ${ }^{15}$ Sua Utopia deve ser compreendida como uma vigorosa sátira política aos costumes da Inglaterra de Henrique VIII. ${ }^{16} \mathrm{O}$ seu conteúdo moral, certamente derivado do humanismo cristão ${ }^{17}$ do autor, funcionou como instrumento de combate em meio ao esforço

14 Como recorda Moses Finley, "Desde que Thomas Morus apresentou ao mundo a palavra "utopia”, no início do século XVI, o termo originou uma gama semântica, ou talvez eu deva dizer um espectro de significados, ampla e complexa, e não menos confusa" (FINLEY, 1989, p. 193).

15 "Depois de Maquiavel, o escritor político mais conhecido do século XVI é Thomas Morus" (MOSCA; BOUTHOUL, 1987, p. 132).

16 "Na primeira parte da obra, o autor esboça um quadro enérgico da Inglaterra, com camponeses expulsos do campo para as cidades, bandos de ladrões, uma justiça cega e cruel, a realeza ávida de riquezas e sempre pronta para a guerra" (HUISMANN, 2000, p. 562).

17 Qual o sentido desta expressão? Segundo Paul Kristeller, “...podríamos llamar humanistas cristianos a todos aquellos intelectuales que aceptaron las enseñanzas del cristianismo y eran miembros de alguna de las iglesias, sin que por ello examinaran necesariamente temas religiosos o teológicos en sus escritos literarios o ensayísticos (KRISTELLER, 1993, p. 107; veja também KENNY, 1992, p. 19 et seq.). 
intelectual de intervir numa realidade social e econômica que se tornava cada vez mais materialista: "antes de iniciar a descrição da maravilhosa ilha de Utopia, More traça um quadro sombrio da situação econômica e social da Inglaterra, desgastada pelos impostos, pela miséria e pelos ladrões" (PETIFILS, 1977, p. 17).

Na análise de George SABINE (1964, p. 421),

Esse ataque aos princípios econômicos dos empreendimentos comerciais, contudo, era realmente motivado por saudades do passado. Retroagia ao ideal, difícil, embora, de se tornar realidade, de uma comunidade cooperativa, que a nova economia estava substituindo. ${ }^{18}$

Neste sentido, surgem as seguintes interrogações: ao conceber o ideal de sua república perfeita, Morus teria concebido o desejo de retroceder no tempo para refundar uma ordem social primitiva, que ele imaginou como o melhor dos mundos? Ou o regime comunitário, que vai inspirar os socialistas de todas as extrações representa um avanço, ao menos se comparado às sociedades políticas da Europa no início da Época Moderna?

Ao que parece, a proposta de Morus é um misto de conservadorismo e de inovação. É conservadora na medida em que propõe um retorno a certas formas de antanho e inovadora no sentido em que representa um avanço sem precedentes, pelas situações inéditas que visualiza na história efetiva da Europa. Em qualidade, é inegavelmente mais inovadora, dentre muitas outras coisas, devido à sua idéia mestra: a abolição da propriedade privada, que vai além do fim da propriedade dos meios de produção, entrando mesmo porta adentro dos cidadãos (recorde-se que a economia monetária foi extinta e até as moradias eram comuns de tempos em tempos). De fato, o ouro na Utopia era utilizado para fabricar urinóis e outros recipientes destinados a fins tão pouco nobres quanto estes. Em sua biografia intelectual de Morus, Anthony Kenny explora o ridículo que as embaixadas estrangeiras faziam na ilha, ao se exibirem com indumentárias magnificentes enfeitadas de ouro e gemas. Assim ornados, os

18 Na análise de Kenneth Rexroth, "Más de la mitad del libro representa la mejor de todas la denuncias de las enfermedades sociales que acompañaran la muerte de la entidad política medieval. Es una magistral acusación de una sociedad que está fundada en avaricia, y donde homo homine lupus es la regla de hierro" (REXROTH, 1993, p. 148). A propósito da consciência crítica de Morus, consulte também ROMANO; TENENTI, 1972, p. 149. Numa análise paralela das obras de Morus e de Campanella, a filósofa marxista Agnes Heller sugere a seguinte interpretação acerca da crítica social dos utopistas modernos: "Mesmo quando ainda nascente, o capitalismo dava já necessariamente origem a seus próprios críticos, que se opunham à realidade da época com base nos próprios princípios e possibilidades a ela inerentes" (HELLER, 1982, p. 292). 
embaixadores eram confundidos com bufões pelos utópicos, e seus empregados mais humildes com os chefes da embaixada. (cf. KENNY, 1992, p. 44). Como afirma Jean-Christian PETIFILS (1977, p. 18),

essa crítica virulenta ao capitalismo agrário de sua época explica o interesse que os marxistas manifestam em relação a More, que consideram talvez um pouco apressadamente, como um de seus precursores. More, com efeito, não acredita nas revoluções como remédio político, pois as conseqüências que acarretam sempre lhe parecem piores que o mal que deveriam curar.

Segundo Abbagnano, historiador italiano da filosofia, a Utopia de Morus está fora da consideração filosófica como gênero literário. De acordo com este autor, o tipo de abordagem do humanista inglês sempre foi muito divulgado e ainda continua a ser, transformando-se, na última encarnação, nos livros de ficção científica. Para Abbagnano, a avaliação da utopia é um problema filosófico, tanto a expressa em forma romanesca, quanto a expressa em forma de ideologia. (cf. ABBAGNANO, 1985). E, acerca dessa avaliação, os teóricos ainda não chegaram a um bom entendimento. Augusto Comte confiava à utopia a tarefa de melhorar as instituições políticas e desenvolver as idéias científicas. Marx e Engels, ao contrário, condenaram como utópicas as formas pelas quais o socialismo se metamorfoseara, na seqüência das obras de Proudhon, Fourier e Saint-Simon. Os primeiros contrapunham a estes o socialismo científico "que prevê a transformação infalível do capitalismo em sistema comunista, mas exclui qualquer previsão sobre a forma que assumirá a sociedade futura e qualquer programa para ela" (ABBAGNANO, 1985, p. 915). Karl Manheim considerou a utopia "como destinada a realizar-se. A utopia seria nesse sentido o fundamento de toda renovação social". ${ }^{19}$ Norberto Bobbio, na "Introdução" à sua Teoria das formas de governo, afirma que se pode distinguir pelo menos três maneiras diferentes com que já se elaboraram modelos do melhor Estado:

por meio da idealização de uma forma histórica; combinando numa síntese ideal os vários elementos positivos de todas as formas, de modo a eliminar seus defeitos, conservando-lhes as qualidades e, por fim, a construção da melhor República pode ser uma pura elaboração

19 Moses Finley repercute a opinião de Manheim: “A utopia transcende a realidade social conhecida; ela não é transcendental num sentido metafísico. Tudo isso é que diferencia as utopias sociais do Jardim do Éden..." (FINLEY, 1989, p. 196). 
intelectual, completamente abstrata em relação à realidade histórica, como pode ser confiada à imaginação poética, que se compraz em planejar Estados ideais que nunca existiram e nunca existirão. Tratase do pensamento utópico que aparece em todas as épocas, especialmente durante as grandes crises sociais, elaborado por criadores apaixonados e inspirados. (BOBBIO, 1986, p. 35-36).

Para Walter Theimer, a obra fundadora e matriz das diversas linhagens de utopias é a República, de Platão (428-346 a.C.) que, inclusive, está na base da Utopia de Thomas Morus. ${ }^{20}$ Mas é bom lembrar que se a República é a matriz, não foi seguida à risca pela tradição. ${ }^{21}$ Morus diverge em muitos aspectos de sua fonte de inspiração. ${ }^{22}$ Naturalmente, a Utopia de Morus não foi "um simples divertimento de um letrado" (PETIFILS, 1977). Os problemas de seu tempo determinaram os elementos de sua singularidade em relação a seu modelo de inspiração. As questões sociais que afetavam Morus no universo ampliado da Europa do Renascimento ultrapassam em muito as reflexões morais de Platão, movido, certamente, pelos valores mais estreitos e circunstanciais da antiga cidade grega, unidade política menor e, portanto, muito menos complexa que a Inglaterra e a Europa de Morus.

O livro de Morus é paradigmático do gênero utópico moderno porque lançou as bases sobre as quais os demais modelos se constituíram. Deste modo, um traço comum e predominante está no fato de os autores utópicos pensarem na constituição de sociedades comunitárias, o que leva suas obras a serem reunidas sob a etiqueta comum de "socialismos utópicos". ${ }^{23}$ Assim é que, na análise de Theimer, não há registro na história da teoria política, de

20 “...su célebre Utopía, por original que sea su contenido, dificilmente habría sido concebida sin el conocimento de la República, de Platón” (KRISTELLER, 1993, p. 86).

21 Há autores que ressaltam ainda a influência de duas outras obras sobre o pensamento político de Thomas Morus: Germânia, de Tácito, e $O$ elogio da loucura, de Erasmo, obras estas que teriam aguçado nele a sensibilidade para destacar as coisas desarrazoadas existentes no mundo (cf. MOSCA; BOUTHOUL, 1987, p. 133 e HUISMANN, 2000, p. 562).

22 “A seu modo, Thomas More concordava com Platão nessa questão (um programa educacional para a sociedade), mas divergiam totalmente a respeito de minha segunda antítese: o primeiro elaborou uma utopia quase que completamente igualitária, o segundo uma utopia estritamente hierárquica" (FINLEY, 1987, p. 202). Para se ampliar as notáveis diferenças entre ambos, consulte ainda (MOSCA; BOUTHOUL, 1987, p. 135, PETIFILS, 1977, p. 19).

23 Este é precisamente o título do livro de Jean-Jacques Petifils, Les socialismes utopiques, obra que aborda um sem-número de concepções utópicas, da Antigüidade ao século XX (cf. PETIFILS, 1997). Aliás, o historiador alemão Raymond Gettell nos lembra que as instituições e idéias comunitárias expressas pela utopias não são de origem recente, do século XIX. Já apareciam na Grécia antiga, particularmente em Esparta e, com muita força também, na Idade Média, "na organização agrícola dos feudos, das guildas nas cidades e das ordens monásticas” (GETTELL, 1950, p. 432). 
utopias que se constituam em torno da construção de modelos sociais do tipo liberal e capitalista, até porque as utopias modernas se consolidaram cerrando fileiras contra as sociedades deste gênero. (cf. THEIMER, 1970, p. 301). Sociedade cooperativa é a expressão-chave para se compreender o ideal utópico de Morus, bem como, já no século XVII, o de Campanella (A cidade do sol), o de Bacon (Nova Atlântida), o de Harrington (Oceana). ${ }^{24}$

A maior parte destas e outras utopias do início da Época Moderna refletem um ideal localista e agrário típico das sociedades cristãs medievais. A cultura cristã na Idade Média acreditou verdadeiramente na possibilidade de aplicação prática de princípios como a cooperação fraterna entre os homens. Este é o conteúdo de muitas heresias medievais, que quiseram refundar a ordem social sobre princípios morais e políticos mais próximos dos ideais do cristianismo primitivo. ${ }^{25}$ Morus foi adversário do luteranismo e defendeu a renovação da Igreja católica, que deveria professar uma nova religiosidade, baseada no Novo Testamento e resguardada do fanatismo e das superstições. Este clima de irenismo, que ele certamente aprendeu e compartilhou com Erasmo, é um elemento central do universo cultural de sua ilha imaginária. ${ }^{26}$

Dessa forma, a utopia dá um salto para fora da história, projetando-se, muitas vezes, em regiões e épocas colhidas entre as nuvens, como o universo mágico da terra da cocanha, admiravelmente estudado por Jean DELUMEAU (1984). Como recorda ABBAGNANO (1985, p. 914), a utopia pode permanecer

como aconteceu e acontece, no estado de simples aspiração ou plano genérico, resolvendo-se em uma espécie de evasão da realidade vivida. Mas pode acontecer que a utopia se torne uma força de transformação da realidade em ato e assuma corpo e consistência bastante para transformar-se em autêntica vontade

24 "Na linha de Thomas More, o gênero 'utopia' floresce, traduzindo bem a aspiração de muitos por mudanças sociais profundas. (...) Claro, a cidade utópica dá grande importância, sobretudo em Bacon, à ciência" (JERPHAGNON, 1992, p. 123). No mesmo sentido reflete Bernard Galand: "Não só a palavra 'Utopia', neologismo criado pelo autor, entrou na linguagem corrente, como também as idéias de More serviram de fundamentos para toda a filosofia política moderna. Disseram muitas vezes que More era de certa forma o pai fundador do socialismo. Talvez" (GALAND, 2001, p. 714). Em sentido complementar à carreira do gênero aberta pela obra de Morus, Petifils afirma que a Utopia de Morus é indubitavelmente a mais conhecida e a mais importante, a tal ponto que servirá de nome genérico para designar as ficções políticas (cf. PETIFILS, 1977, p. 16).

25 Esta perspectiva de um socialismo primitivo que aparece em Morus está expressa no verbete "Utopie" do excelente Robert, Dictionnaire des noms propres: "Divisé en deux parties, l'ouvrage débute par une critique da la proprieté privée et du regime monarchique, où l'auteur vise particulièrement l'Angleterre et la France. Il décrire ensuite l'organisation économique, sociale, politique, et culturelle de l'île d'Utopie ("nulle part"), où règne un communisme ideal" (ROBERT, 1997, p. 2119).

26 "As regras são invertidas na República de Utopia: ali se prescreve não prejudicar ninguém em nome da religião. Ao contrário, a intolerância e o fanatismo são punidos com o exílio e a servidão” (HUISMANN, 2000, p. 562). 
inovadora e encontrar os meios de inovação. Em geral, a palavra é considerada mais com referência à primeira que à segunda. ${ }^{27}$

Esta formulação do conceito de utopia, segundo parece, vai ao centro da questão, ao propor a seguinte bipolaridade: ou a utopia é um salto no vazio, fruto muitas vezes de elaborações fantasiosas que dão de ombros para realidades históricas concretas, ou pode também ser um sonho triunfante, desde que alavancado por meios materiais e pelo firme desejo de transformação. No presente caso, o ideal utópico configurou-se como um salto em queda livre no vácuo, haja vista que não encontrou espaço de sustentação em seu mundo histórico: a Inglaterra à época da afirmação do absolutismo dos Tudor. E George Sabine lamenta a aplicação prática completamente nula da obra de Morus:

Se um ideal moral digno pode merecer pena, este foi certamente o de More (...). Expressava, como a própria vida de More, a razoabilidade e a largueza de vistas do humanismo e, ao mesmo tempo, a futilidade de uma aspiração moral que não podia enfrentar a dura realidade. (...) Por esse motivo, a Utopia pode ser encarada como um episódio relativamente isolado e sem importância na filosofia política de sua época. Ilustrava antes as últimas manifestações de um velho ideal do que uma voz autêntica da época que se avizinhava. (SABINE, 1964, p. 422).

E a Europa das Guerras de Religião, que foram atiçadas pela expansão internacional da Reforma, criou o clima fratricida que é o exato oposto do ambiente necessário para a realização da utopia política. O ideal de Morus naufragou nas águas turbulentas que caracterizam todo o século XVI, um tempo de fanatismo, de desordem e de guerras intermináveis entre as monarquias em busca de satisfazerem os novos interesses econômicos emergentes na era do mercantilismo. Mas o seu pensamento utópico continuou vivo e muito invocado através dos tempos, notadamente em momentos de crises agudas na história do Ocidente. Sua obra é uma espécie de reservatório renovável. Neste manancial bebem aqueles que, por cinco séculos e ainda hoje, procuram idéias para fundar o que poderíamos denominar por ilhas desconhecidas. Esta é a longuíssima história dos lugares imaginários. Hoje em dia, num desses momentos em que a

27 Morus parece ter ficado no meio termo. Exemplo disso é a própria confissão um tanto desesperançada de Thomas Morus ao término de seu livro: “....se de um lado não posso concordar com tudo o que disse este homem [recorde-se que a obra baseia-se nas histórias contadas a Morus por um navegador, Hythlodey] de outro lado confesso sem dificuldades que há entre os utopianos uma quantidade de coisas que eu aspiro ver estabelecidas em nossas cidades" (MORE, 1979, p. 314). 
história parece entrar numa outra encruzilhada, a atualidade de sua Utopia parece ganhar uma vitalidade ainda maior. Como afirmou um historiador francês acerca da Utopia, "se não é a melhor das repúblicas, é a melhor das utopias" (DERMENGHEM, 1927, p. 15). Com efeito, em seu gênero, ela é o clássico dos clássicos.

\section{Referências}

ABBAGNANO, N. Dicionário de Filosofia. São Paulo: Mestre Jou, 1985.

BOBBIO, N. A teoria das formas de governo. Brasília: UnB, 1986.

BURKE, P. Montaigne. Oxford: Oxford University Press, 1994.

DELUMEAU, Jean. A civilização do Renascimento. Lisboa: Estampa, 1984. v. 2.

DERMENGHEM, E. Thomas Morus et les utopistes de la Renaissance. Paris: Plon, 1927.

ERASMO. Elogio da loucura. In: Erasmo e Thomas More. São Paulo: Abril Cultural, 1979.

FINLEY, M. Utopismo antigo e moderno. In: .Uso e abuso da História. São Paulo: Martins Fontes, 1989.

FRANCO JÚNIOR, H. Cocanha, a história de um país imaginário. São Paulo: Cia. das Letras, 1998.

GALAND, B. Sir Thomas More. In: HUISMANN, D. Dicionário dos filósofos. São Paulo: Martins Fontes, 2001.

GETTEL, R. História das idéias políticas. Lisboa: Editorial Inquérito, 1950.

HELLER, A. O homem do Renascimento. Lisboa: Editorial Estampa, 1982.

HUISMANN, D. Dicionário das obras filosóficas. São Paulo: Martins Fontes, 2000.

JERPHAGNON, L. História das grandes filosofias. São Paulo: Martins Fontes, 1992.

KENNY, Anthony. Tomás Moro. México: Fondo de Cultura Económica, 1992.

KRISTELLER, P. El pensamiento renascentista y sus fuentes. México: Fondo de Cultura Económica, 1993.

LE GOFF, J. A civilização do Ocidente Medieval. Lisboa: Estampa, 1983. v. 2.

MAQUIAVEL. A arte da guerra e outros ensaios. Brasília: EUB, 1982. 
MINOGUE, K. Política: uma brevíssima introdução. Rio de Janeiro: Zahar, 1998.

MORE, T. A Utopia. In: Erasmo e Thomas More. São Paulo: Abril Cultural, 1979.

PETIFILS, J-C. Thomas More. In: Les socialismes utopiques. Paris: Presses Universitaires de France, 1977.

PRÉLOT, M. As doutrinas políticas. Lisboa: Presença, 1974. v. 02.

REXROTH, K. Recordando a los clásicos. México: Fondo de Cultura Económica, 1993.

RIBEIRO, R. J. Apresentação. In: HOBBES, T. Do Cidadão. São Paulo: Martins Fontes, 2002.

ROBERT. Le petit Robert des noms propres. (Dictionnaire Illustré). Paris: Dictionnaires Le Robert, 1997.

ROMANO, R.; TENENTI, A. Los fundamentos del mundo moderno. Madrid: Siglo XXI, 1972.

SABINE, G. História das teorias políticas. Rio de Janeiro: Editora Fundo de Cultura, 1964.

SARGENT, Daniel. Thomas More. Paris: Desclée de Brouwer, [s.d.]

SICHEL, E. O Renascimento. Rio de Janeiro: Zahar, 1977.

SKINNER, Q. A Utopia e a crítica ao humanismo. In: . As fundações do pensamento político moderno. São Paulo: Cia. das Letras, 1996.

THEIMER, W. História das idéias políticas. Lisboa: Arcádia, 1970.

TOUCHARD, J. (Org.). História das idéias políticas. Lisboa: PEA, 1970. 